\title{
Prevalence of antibodies to equine alphaviruses in the State of Pará, Brazil
}

\section{Prevalência de anticorpos para alphavirus em equinos do estado do Pará, Brasil}

\author{
Alexandre do Rosário Casseb ${ }^{1 *}$, Thais Costa Brito ${ }^{1}$, Maria Rogéria Menezes da Silva ${ }^{1}$, \\ Jannifer Oliveira Chiang ${ }^{2}$, Lívia Caricio Martins², Sandro Patroca da Silva², \\ Daniele Freitas Henriques ${ }^{2}$, Livia Medeiros Neves Casseb ${ }^{2}$, Pedro Fernando da Costa Vasconcelos ${ }^{2}$
}

\begin{abstract}
The State of Pará comprises $26 \%$ of Brazilian Amazon region, where a large diversity of arboviruses has been described. This study sought to assess the prevalence and distribution of hemagglutination inhibition (HI) antibodies against antigens of four alphaviruses (Togaviridae: Alphavirus) from the species: Eastern equine encephalitis (EEEV), Western equine encephalitis (WEEV), Mayaro virus (MAYV), and Mucambo virus (MUCV) in 753 serum samples of horses in Pará State, Brazil. All investigated arboviruses were detected and indicate that horses are susceptible to these alphaviruses, and show evidences of their active circulation in farm animals in the Brazilian Amazon.
\end{abstract}

KEYWORDS: Eastern equine encephalitis virus; Western equine encephalitis virus; Mayaro virus; Mucambo virus; hemagglutination inhibition test.
RESUMO: O estado do Pará corresponde a 26\% da Amazônia brasileira, onde uma grande diversidade de arbovírus foi descrita. Este estudo procurou avaliar a prevalência e a distribuição de anticorpos inibidores da hemaglutinaçáo $(\mathrm{IH})$ contra antígenos de quatro alfavirus (Togaviridae: Alphavirus), das espécies: Vírus da encefalite equina do leste (EEEV), Virus da encefalite equina do oeste (WEEV), Virus mayaro (MAYV) e Virus mucambo (MUCV), de 753 amostras de soro de equinos no estado do Pará, Brasil. Todos os arbovirus pesquisados foram detectados, indicando que os equinos são suscetíveis a esses Alphavirus e mostrando evidências de sua circulação ativa em animais de fazenda na Amazônia brasileira.

PALAVRAS-CHAVE: Vírus da encefalite equina do leste; Vírus da encefalite equina do oeste; Vírus mayaro; Vírus mucambo; teste da inibição da hemaglutinação. 
With few exceptions, arboviruses are zoonosis, once they are maintained in nature by cycles of nonhuman vertebrates and hematophagous arthropods; the Pan-Amazonia is the largest arbovirus reservoir in the world, and the Brazilian Amazon hosts the largest variety of known and isolated arboviruses (VASCONCELOS et al., 2005). In Brazil, especially in the Brazilian Amazon, there are a large number of different species cohabitating between hematophagous diptera and wild vertebrates. Disequilibrium in this ecosystem is associated with factors such as deforestation, highways and dam construction (DÉGALLIER et al., 1992, VASCONCELOS, 1999), colonization and urbanization of new areas after railway construction, and improper use of the land and subsoil (VASCONCELos et al., 2001). All of these factors contribute to the emergence of new arboviruses and arboviral diseases.

The Togaviridae family comprises the Alphavirus and Rubivirus genera. The genus Alphavirus infects a variety of vertebrates, including humans. Eleven serotypes were associated with human disease, and at least eight were responsible for outbreaks: Eastern equine encephalitis virus (EEEV), Western equine encephalitis virus (WEEV), Venezuelan equine encephalitis virus (VEEV), Mayaro virus (MAYV), O'Nyong-nyong virus (ONNV), Ross River virus (RRV), Chikungunya virus (CHIKV), and Getahvirus (GEV) (CALisher et al., 1980). Infections in domestic herbivores by arboviruses belonging to the genus Alphavirus manifest as systemic, encephalic, and hemorrhagic syndromes. Encephalitis is more common in horses, which are mostly affected by EEEV, VEEV, and WEEV (WeAVER; ReIsen, 2010).

Although 210 arboviruses have been isolated in Brazil, the vast majority of them have been found in the Brazilian Amazon (Vasconcelos et al., 2005; Azevedo et al., 2009), and, to the best of our knowledge, there have been no studies that focused on investigating the role of horses in the circulation of alphaviruses in Brazilian Amazon. To address this question, we have evaluated the prevalence of antibodies in horses from Pará State, Brazil, to determine which alphaviruses are circulating.

Blood was collected throughout 2009 from animals living in the six mesoregions of the Pará State (Figure 1). After proper restraint of the animals and local asepsis, the jugular vein was punctured, without anticoagulant, with a vacuum system. About $5-10 \mathrm{~mL}$ of blood was collected and left to rest for approximately 90 minutes to allow coagulation and serum separation before it was subjected to centrifugation at $2,000 \times \mathrm{g}$ for 5 minutes. The serum samples were transported on ice and then stored at $-70^{\circ} \mathrm{C}$ until analyzed by serologic testing. A total of 753 serum samples were collected by horses aged 2 years or older, without arboviruses vaccination and born and raised at the collection sites.

The hemagglutination inhibition (HI) test was performed according to the microplate-adjusted protocol described by SHOpe (1963). This test was performed with antigens from EEEV, WEEV, MAYV, and MUCV isolated in Brazil.

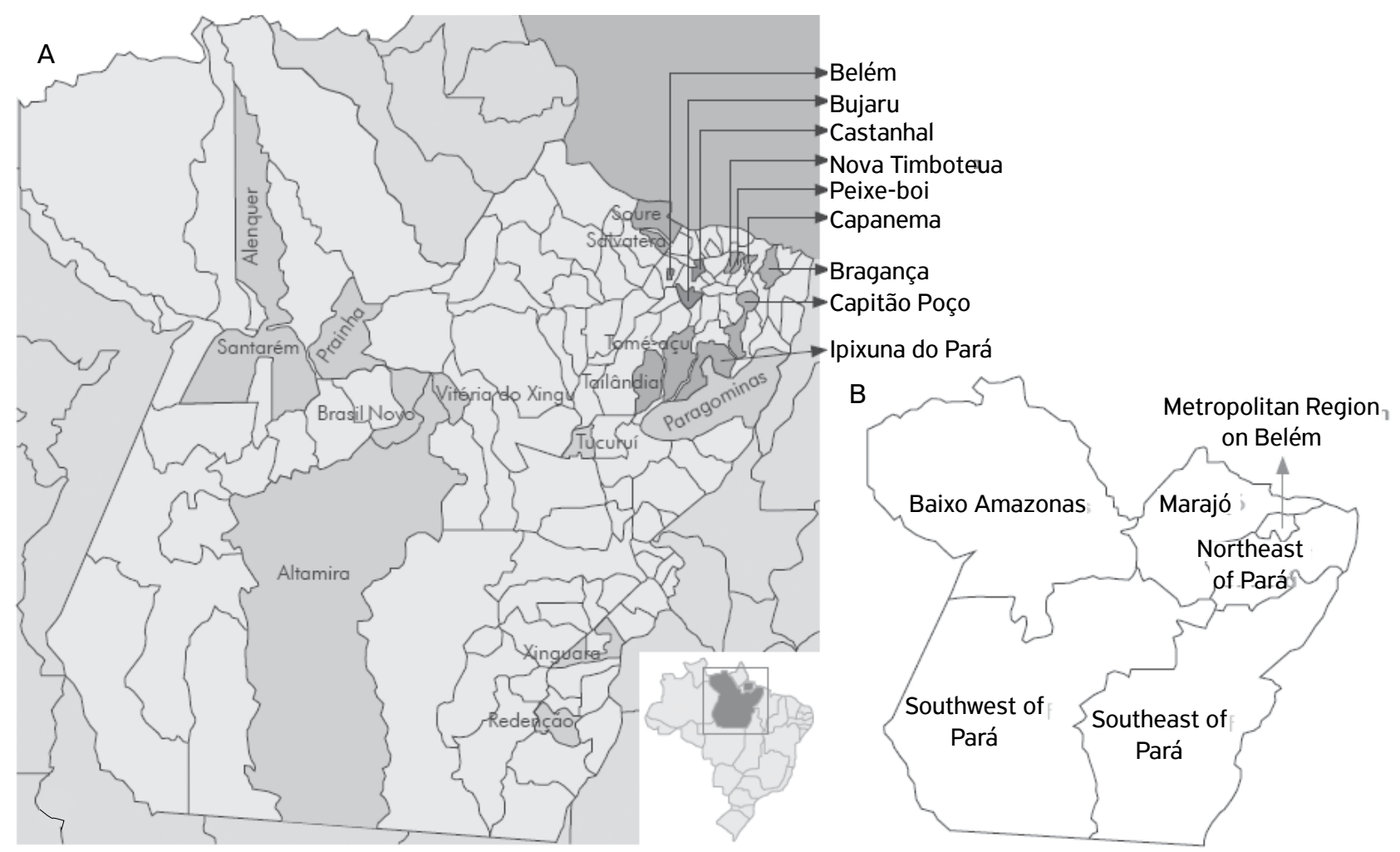

A: collecting municipalities; B: the division into mesoregions of Pará State.

Figure 1. Schematic representation of the Pará State indicating were collected from the domestic herbivores serum samples. (A) Collecting municipalities, (B) The division into mesoregions of Pará State. 
The criteria by Rodrigues et al. (2010) for positivity were chosen. Positive reactions were classified as either monotypic reactions (MR; reaction against only one antigen or reaction that was at least four-fold stronger against one antigen compared to all other antigens of the same viral genus), heterotypic reactions (HR; reactions against two or more viruses exhibiting similar titers or the predominance of a given antigen was less than four-fold than the others), or total reactions (TR; monotypic reactions plus heterotypic reactions).

All horses presented high serologic prevalence to the four alphaviruses used in this study. The prevalences for TR, HR, and MR are presented in Table 1. The table shows that all four viruses belonged to the genus Alphavirus, all of which have already been isolated from arthropods and/or wild vertebrates in Brazil and even from humans in the Western hemisphere, and only EEEV and WEEV have been proven to cause disease in horses.

In the Brazilian Amazon, EEEV and WEEV have been isolated from birds, horses, and mosquitoes in the suburbs of Belém and Southern Pará State, Brazil. Antibodies against these arboviruses have also been found, with a low prevalence, in wild mammals (Shope et al., 1966) and birds (DÉGALLIER et al., 1992). The results of this study indicate a broad distribution of these arboviruses in the Brazilian Amazon. It should be emphasized that there is a high prevalence of $\mathrm{HI}$ antibodies against $\mathrm{EEEV}$ and WEEV in unvaccinated horses, which indicates frequent exposure of these animals to mosquitoes that carry theses arboviruses.

Despite the lack of reports on clinical disease in horses in Pará State, Brazil, only one epizootic episode by EEEV has been reported in the city of Bragança in 1962 (CAUSEY et al., 1962), and another in Marajó Island recently (CAMPOs et al., 2013); however, there are no reported cases of encephalitis-like human disease in the Amazon region caused by these arboviruses (Woodall, 2004). Although EEEV causes neurological illness in human beings in the North America (WeAvER; ReISEN, 2010), only two fatal cases had been reported in South America, with one being in Brazil, in the state of the Bahia (AliCE, 1956), and the other one, in Trinidad and Tobago (Corniou et al., 1972). Aguilar et al.

Table 1. Prevalence of $\mathrm{HI}$ antibodies against antigens of four alphaviruses in horses sera with heterotypic reactions (HR), monotypic reactions (MR), and total reactions (TR) obtained in State of Pará, Brazil.

\begin{tabular}{|c|c|c|c|c|c|c|}
\hline \multicolumn{7}{|c|}{ Horses } \\
\hline \multicolumn{7}{|c|}{$N=753$} \\
\hline Virus & HR & MR & TR & \%HR & \%MR & \%TR \\
\hline EEEV & 153 & 74 & 227 & 20.31 & 9.82 & 30.14 \\
\hline WEEV & 148 & 24 & 172 & 19.65 & 3.18 & 22.84 \\
\hline MAYV & 36 & 04 & 40 & 4.78 & 0.53 & 5.31 \\
\hline MUCV & 54 & 09 & 63 & 7.17 & 1.19 & 8.36 \\
\hline Total & 391 & 111 & 502 & 51.92 & 14.74 & 66.66 \\
\hline
\end{tabular}

EEEV: Eastern equine encephalitis virus, WEEV: Western equine encephalitis virus, MAYV: Mayaro virus, MUCV: Mucambo virus.
(2007) believe that the low incidence of severe cases of human encephalitis in South America is probably due to low infectivity and/or non-virulence of the isolated strains of EEEV that circulates in this region.

Some epizootic strains of VEEV may be transmitted from horse-to-mosquitoes-to-human, and the epidemic transmission cycle of VEEV involves horses that serve as the main source of the virus, thus being a source of infection to new hematophagous mosquitoes (Sтотт, 2003). The MUCV subtype III of VEEV (Young; Johnson, 1969) was isolated in Amazonia, and it was associated with sporadic self-limited febrile syndromes in humans in Brazil, Trinidad and Tobago, Surinam, and French Guiana.

The MUCV subtype was isolated in Southeastern Brazil, close to the Ribeira Valley, in the State of São Paulo (Lopes; SACHetta, 1978); however, there are no reports of disease in domestic animals. Nevertheless, a 10-month-old equine experimentally infected via intramuscular route with high doses of MUCV has developed viremia, which lasted for 3 days, with fever 24 hours later, and persistent leucopenia (SHOpe et al., 1964). Additionally, Iversson et al. (1993) found anti-MUCV antibodies in an equine exhibiting encephalitis-like illness in the Brazilian Pantanal.

MAYV was first isolated in Trinidad and Tobago in 1954 (ANDERson et al., 1957) and is frequently isolated in northern South America from humans, wild vertebrates (mainly monkeys), and mosquitoes. Outbreaks in humans caused by this rash febrile disease virus have been frequently reported in Amazon (Azevedo et al., 2009). In this study, the prevalence of $\mathrm{HI}$ antibodies against MAYV was low. There are no reports of disease caused by this virus in domestic animals; however, the clinical syndrome showed by humans presents symptoms that may not be perceived in horses.

The results of this study lead us to the following conclusions: these are preliminary evidences of active alphavirus infections in horses in the Brazilian Amazon; these animals must have been exposed to many thousands of mosquito bites in locations that sometimes serve as transmission foci for those viruses, although there was no evidence that horses are frequently exposed to arboviruses; the results obtained in this study showed evidence of such condition, which may represent a public health risk to humans, who are susceptible to developing diseases caused by alphaviruses; and finally, the horses showed higher prevalence of antibodies in TR and HR, suggesting that these animals can detect the circulation of such alphaviruses.

\section{ETHICS COMMITTEE AND BIOSECURITY}

This study was approved by the Animal Research Ethics Committee (CEPAN) of the Evandro Chagas Institute (IEC) (protocol 054/2009 CEPAN/IEC). 
AGUILAR, P.V.; ROBICH, R.M.; TURELL, M.J.; O'GUINN, M.L.; KLEIN, T.A.; HUAMAN, A.; GUEVARA, C.; RIOS, Z.; TESH, R.B.; WATTS, D.M.; OLSON, J.; WEAVER, S.C. Endemic eastern equine encephalitis in the amazon region of Peru. The American Journal of Tropical Medicine and Hygiene, v.76, n.2, p.293-298, 2007. Disponível em: <http://www.ajtmh.org/content/76/2/293.full. pdf + html $>$. Acesso em: 20 dez. 2013.

ALICE, FJ. Infecção humana pelo vírus "leste" da encefalite equina. Boletim do Instituto Biológico da Bahia, v.3, p.3-9, 1956.

ANDERSON, C.R.; DOWNS, W. G.; WATTLEY, G.H.; AHIN, N.W.; REESE, A.A. Mayaro virus: a new human disease agent. II. Isolation from blood of patients in Trinidad, B.W.I. The American Journal of Tropical Medicine and Hygiene, v.6, n.6, p.1012-1016, 1957. Disponível em: <http://www.ajtmh.org/content/6/6/1012.full. pdf $>$. Acesso em: 20 dez. 2013.

AZEVEDO, R.S.S.; SILVA, E.V.P.; CARVALHO, V.L.; RODRIGUES, S.G.; NUNES NETO, J.P.; MONTEIRO, H.A.O.; PEIXOTO, V.S.; CHIANG, J.O.; NUNES, M.R.T.; VASCONCELOS, P.F.C. Mayaro fever virus. Brazilian Amazon. Emerging Infectious Diseases, v.15, n. 11 , p. 1830-1832, 2009. Disponível em: <http://www. ncbi.nlm.nih.gov/pmc/articles/PMC2857233/>. Acesso em: 22 dez. 2013.

CALISHER, C.H.; SHOPE, R.E.; BRANDT, W.; CASALS, J.; KARABATSOS, N.; MURPHY, F.A.; TESH, R.B.; WIEBE M.E. Proposed antigenic classification of registered arboviruses I. Togaviridae, Alphavirus. Intervirology, v.14, n.5-6, p.229-232, 1980. Disponível em: <http://www.karger.com/Article/Pdf/149190>. Acesso em: 23 dez. 2013.

CAMPOS, K.F.; DE OLIVEIRA, C.H.S.; REIS, A.B.; YAMASAKI, E.M.; BRITO, M.F.; ANDRADE, S.J.T.; DUARTE, M.D.; BARBOSA, J.D. Surto de encefalomielite equina Leste na llha de Marajó, Pará. Pesquisa Veterinária Brasileira, v.33, n.4, p.443-448, 2013. Disponível em: <http://www.pvb.com.br/pdf_artigos/01-052013_10-38Vet\%201428_2985\%2OLD.pdf>. Acesso em: 26 dez. 2013.

CAUSEY, O.R.; SHOPE, R.E.; LAEMMERT, H. Report of an epizootic of encephalomyelitis virus in Pará, Brazil. Revista do Serviço Especial de Saúde Publica, v.12, p.47-50, 1962. Disponível em: <http://iah.iec.pa.gov.br/iah/fulltext/memo_iec/v7p103-106. pdf> Acesso em: 27 dez. 2013.

CORNIOU, B.; ARDOIN, P.; BARTHOLOMEW, C.; INCE, W.; MASSIAH, $V$. First isolation of a south American strain of eastern equine virus from a case of encephalitis in Trinidad. Tropical and Geographical Medicine, v.24, n.2, p.162-167, 1972. Disponível em: <http://www. ncbi.nlm.nih.gov/pubmed/5037688>. Acesso em: 27 dez. 2013.

DÉGALLIER, N.; TRAVASSOS DA ROSA, A.P.A.; VASCONCELOS, P.F.C.; ROSA, E.S.T.; RODRIGUES, S.G.S.F.; SÁ FILHO, G.C.; TRAVASSOS DA ROSA, J.F.S. New entomological and virological data on the vectors of sylvatic Yellow Fever in Brazil. Journal of the Brazilian Association for the Advancement of Science, v.44, n.2/3, p.136-142, 1992. Disponível em: <http://horizon. documentation.ird.fr/exl-doc/pleins_textes/pleins_textes_6/b_ fdi_33-34/38275.pdf>. Acesso em: 28 dez. 2013.

IVERSSON, L.B.; SILVA, R.A.M.S.; TRAVASSOS DA ROSA, A.P.A.; BARROS, L.R.S. Circulation of Eastern equine encephalitis, Western equine encephalitis, Ilhéus, Maguari and Tacaiuma viruses in equines of the Brazilian Pantanal, South America. Revista do Instituto de Medicina Tropical de São Paulo, v.35, n.4, p.355359, 1993. Disponível em: <http://www.scielo.br/pdf/rimtsp/ v35n4/a09v35n4.pdf>. Acesso em: 27 dez. 2013.

LOPES, O.S.; SACHETTA, LA. Isolation of Mucambo virus, a member of the Venezuelan equine encephalitis virus complex in the State of São Paulo, Brazil Revista do Instituto de Medicina Tropical de São Paulo, v.20, n.2, p.82-86, 1978. Disponível em: <http://www. ncbi.nlm.nih.gov/pubmed/675033>. Acesso em: 29 dez. 2013.

RODRIGUES, S.G.; OLIVA, O.P.; ARAUJO, F.A.A.; MARTINS, L.C.; CHIANG, J.O.; HENRIQUES, D.F.; SILVA, E.V.P.; RODRIGUES, D.S.G.; PRAZERES, A.S.C. ; TAVARES-NETO, J.; VASCONCELOS, P.F.C. Epidemiology of Saint Louis encephalitis virus in the Brazilian Amazon region and in the State of Mato Grosso do Sul, Brazil: elevated prevalence of antibodies in horses. Revista Pan-Amazônica de Saude, v.1, n.1, p.81-86, 2010. Disponível em: <http://scielo.iec.pa.gov.br/pdf/rpas/v1n1/v1n1a12.pdf >. Acesso em: 30 dez. 2013.

SHOPE, R.E. The use of micro-hemagglutination-inhibition test to follow antibody response after arthropod-borne virus infection in a community of forest animals. Anais de Microbiologia, v. 11 , p.167-171, 1963. Disponível em: <http://iah.iec.pa.gov.br/iah/ fulltext/memo_iec/v7p 175-178.pdf>. Acesso em: 30 dez. 2013.

SHOPE, R.E.; CAUSEY, O.R.; ANDRADE, A.H.P.; THEILER, M. The Venezuelan equine encephalomyelitis complex group $A$ arthropodborne viruses, including mucambo and pixuna from the Amazon region of Brazil. The American Journal of Tropical Medicine and Hygiene, v.13, n.5, p.723-727, 1964. Disponível em: <http:// iah.iec.pa.gov.br/iah/fulltext/memo_iec/v7p191-202.pdf> Acesso em: 30 dez. 2013.

SHOPE, R.E.; ANDRADE, A.H.P.; BENSABATH, G.; CAUSEY, O.R.; HUMPHREY, P.S. The epidemiology of EEE, WEE, SLE and Turlock viruses, with special reference to birds, in a tropical rain forest near Belém, Brazil. American Journal of Epidemiology, v.84, n.3, p.467-477, 1966. Disponível em: <http://iah.iec.pa.gov.br/iah/ fulltext/pc/monografias/iec/memo_iec/vol8/v8p 105-125.pdf >. Acesso em: 30 dez. 2013.

STOTT, J.L. Togaviridae e Flaviviridae. In: HIRSH, D.C., ZEE, Y.C. Microbiologia Veterinária. Rio de Janeiro: Guanabara Koogan, 2003. p.358-367.

VASCONCELOS, P.F.C. Emergence of Arboviruses in Brazilian Amazon region. Virus. Reviews \& Research, v.4 (suppl. 1), p.4849, 1999. Disponível em: <http://iah.iec.pa.gov.br/iah/fulltext/ pc/artigos/1999/VirReviewResearch\%2Ov4Supp 1p48-49\%20 Nov\%201999.pdf>. Acesso em: 31 dez. 2013. 
VASCONCELOS, P.F.C.; TRAVASSOS DA ROSA, A.P.A.; RODRIGUES, S.G.; TRAVASSOS DA ROSA, E.S.; TRAVASSOS DA ROSA, J.F.S. Inadequate management of natural ecosystem in the Brazilian Amazon region results in the emergence and reemergence of Arboviruses. Cadernos de Saúde Pública, v. 17 (Suplemento), p.155-164, 2001. Disponível em: <http://www.scielo.br/pdf/ csp/v17sO/3892.pdf>. Acesso em: 31 dez. 2013.

VASCONCELOS, P.F.C. Arboviroses. In: FOCACCIA, R. Veronesi-Tratado de Infectologia. $3^{\text {th }}$ ed. São Paulo: Atheneu, 2005. p.289-302.

WEAVER, S.C.; REISEN, WK. Present and future arboviral threats. Antiviral Research, v.85, p.328-345, 2010. Disponível em:
<http://www.idpublications.com/journals/PDFs/AVRES/AVRES_ MostDown_2.pdf>. Acesso em: 31 dez. 2013.

WOODALL, J. Notas históricas de alguns arbovírus isolados no laboratório de vírus de Belém da Fundação Rockefeller. In: III Simpósio Internacional de Arbovírus dos Trópicos e Febres Hemorrágicas. Belém: Instituto Evandro Chagas, 2004. p.12-13.

YOUNG, N.A.; JOHNSON, KM. Antigenic variants of Venezuelan equine encephalitis virus: their geographic distribution and epidemiologic significance. American Journal of Epidemiology, v.89, n.3, p.286-307, 1969. Disponível em: <http://aje.oxfordjournals. org/content/89/3/286.full.pdf>. Acesso em: 31 dez. 2013. 